\title{
Accounting
}

\section{Investigating the factors on attracting resources for urban development in Vietnam}

\section{Tuan Anh Nguyen a and Thanh Thuy $\mathrm{Cu}^{\mathrm{a}^{*}}$}

\begin{tabular}{l}
${ }^{a}$ Hanoi Architectural University, Vietna \\
\hline C H R O N I C L E \\
\hline Article history: \\
Received: September 28, 2020 \\
Received in revised format: \\
December 282020 \\
Accepted: December 28, 2020 \\
Available online: \\
December 28, 2020 \\
\hline Keywords: \\
Urban Development \\
Attracting \\
Resources \\
Vietnam
\end{tabular}

\section{Introduction}

Urban development has become an inevitable trend of each country in general and cities in particular and promotes economic development inevitably. In the period 2011-2020, Vietnam continued to promote economic growth and the process of urbanization forcefully and effectively. By the end of 2018, the urbanization rate of the whole country reached 38.4\%; the total number of urban areas in Vietnam was 833 cities. The urban population growth rate is over 3\% per year. Urbanization is most concentrated in the Southeast/region, Ho Chi Minh City (64.15\%), the lowest in the Northern Midlands and Mountains $(21.72 \%)$. The rate of urbanization of Vinh Phuc province in 2019 was $25.63 \%$. Vietnam has reaped many benefits from the urbanization process. The urban area not only creates gross domestic product (GDP) growth but also contributes positively to the transformation of Model Shifts and growth structure in the long term. National growth drivers are primarily concentrated in urban areas due to strong growth in industry and services. Over the period 2011-2020, the country's economic structure continued to shift to non-agriculture, thanks to the strong growth of the industrial, construction, and service sectors. The growth rate of urban population services remained a stable rate (about 3\%/year). The proportion of labor in the agricultural sector decreased rapidly from $60 \%$ (2008) to $40 \%$ (2017). This shift reflects the process of industrialization, modernization, and urbanization, with population growth within urban (administrative) boundaries averaging nearly 1 million people per year, from

* Corresponding author.

E-mail address: thanhthuyktdt85@gmail.com (T.T. Cu)

(C) 2021 by the authors; licensee Growing Science, Canada doi: $10.5267 /$ j.ac.2021.1.014

\begin{abstract}
A B S T R A C T
This study is carried to analyze the factors influencing the attracting resources for urban development in a case study in Vietnam. The research findings show that factors such as human resources, local olicies, infrastructure system, local advantages, and international integration were the most influential factors on the ability to attract resources. At the same time, the study carried out the
forecast of the need to use resources for urban development of Phuc Yen city in Vietnam. The resources forecasted in the study are human resources and financial resources. For human resources, with the data collected through surveys and evaluation of enterprises - an important subject promoting the socio-economic development of the city, the authors assessed the adaptive capacity of this human
resource to serve the development goals of the urban. As for financial resources, the study predicts the demand for capital for industry, agriculture, and services of Phuc Yen City by 2030. The research findings are the basis for proposing solutions to support and promoting the attraction of resources for urban development of Phuc Yen City, Vietnam.
\end{abstract}


24.6 million ( 2008) to over 33 million people (2018). Urbanization has contributed to creating resources in the socio-economic development of the country. The urban economy contributes about $70 \%$ of the national GDP, the budget revenue indicators of the provinces and big cities show that, in general, economic growth in urban areas is from $12 \%$ to an average. $15 \%, 1.2$ to 1.5 times higher than the national average (See Table 1).

Table 1

Rate of urbanization in all regions of Vietnam

\begin{tabular}{|c|c|c|c|c|c|}
\hline \multirow{2}{*}{$\begin{array}{l}\text { Year } \\
\text { Province, City }\end{array}$} & \multicolumn{2}{|c|}{2000} & \multicolumn{2}{|c|}{2015} & \multirow{2}{*}{$\begin{array}{c}\mathbf{2 0 3 0} \\
\text { Rate of } \\
\text { urbanization }\end{array}$} \\
\hline & $\begin{array}{c}\text { Rate of } \\
\text { urbanization }\end{array}$ & Region Hierarchy & $\begin{array}{c}\text { Rate of } \\
\text { urbanization }\end{array}$ & Region Hierarchy & \\
\hline Hanoi & 34.5 & 1 & 48.8 & 1 & $56-70$ \\
\hline Vinh Phuc & 10.7 & 6 & 23.3 & 5 & 63-68 \\
\hline Bac Ninh & 9.5 & 7 & 28.6 & 3 & $55-60$ \\
\hline Hai Duong & 14.1 & 4 & 24.1 & 4 & $55-60$ \\
\hline Hung Yen & 9.4 & 8 & 13.1 & 9 & $50-55$ \\
\hline Ha Nam & 8.0 & 10 & 15.5 & 8 & $43-48$ \\
\hline Hoa Binh & 13.8 & 5 & 15.5 & 8 & $43-48$ \\
\hline Thai Nguyen & 21.9 & 2 & 34.1 & 2 & $45-50$ \\
\hline Bac Giang & 8.2 & 9 & 11.4 & 10 & $40-45$ \\
\hline Whole country & 24.2 & & 33.9 & & 50 \\
\hline
\end{tabular}

Source: Statistical Yearbook 2015 and Capital Region construction planning

Vinh Yen city is one of the major cities of Vinh Phuc province, which have significant contributions to the general economic development of Vinh Phuc province as well as of Vietnam, at the same time, the urbanization rate of Vinh Phuc province is also in the top group of Vietnam - this may look like a typical case of urban development in Vietnam. To be able to develop more Phuc Yen City, the resource requirements play a leading role. This study is carried to analyze and calculate the need to mobilize resources for urban development, viz., the chief resources mentioned are financial resources and human resources. Also, the study quantifies the impact of these factors on the ability to attract resources for urban development. On that basis, there will be recommendations to promote the positive factors and limit the negative factors affecting the ability to mobilize resources for urban development.

The results of the study are the basis for proposing recommendations to contribute to urban development in general and the case study in Phuc Yen City of Vietnam in particular.

\section{Overview of research related to the subject}

Various factors are influencing the mobilization of resources for socio-economic development as well as for urban development, in fact, studies by Dunning (1997), Kotler (2002), Gilmore et al. (2003) show that infrastructure may attract resources, specifically and it is an investment capital source, which is one of the most important resources, serving national socio-economic development goals. In infrastructure resources, the scales mentioned include communication, traffic, technology development, etc. Meanwhile, Dunning (1997), Kotler (2002), Gilmore (2003), Le Hoang Ba Huyen (2012) also mentioned local advantages as one of the significant factors affecting the attraction of investment resources. Local benefits are mentioned by the above studies when considering aspects such as the market for consumer products, advantages of natural conditions such as geographical location, natural resources, raw material areas, etc. Alam and Stafford (1985), Dunning (1997), Kotler (2002), Gilmore et al. (2003), Le Hoang Ba Huyen (2015) mentioned policy factors and local government attract resources. Whether resources are attracted or not depends mostly on local direction and policies. These studies address this factor including specific economic policies and economic management institutions such as open incentives and preferential policies which are the support policies of the government or locality including taxes, land rent, service assistance. Dunning (1997), Kotler (2002), Le Hoang Ba Huyen (2012) mentioned the human resource factor, which is a decisive factor and plays an essential role in attracting resources from the perspective of businesses. Human resources mentioned include the quantity and quality of labor that ensure that they have qualifications and skills that are suitable for investors' needs. Responding resources will contribute positively in attracting resources for urban development of the locality. Several other studies were performed in the direction towards building livelihood strategies for people who lose land in the process of urbanization and construction of industrial parks of several authors: Tran Quang Tuyen (2013), Tuyen and Van Huong (2014), Benayas et al. (2007), Bryceson (1996), Jansen et al. (2006) etc. These studies identified the income status of the households after land loss, the employment status of the people, analyzed the factors affecting the livelihoods of people who lose land. The elements selected for analysis have quite a lot of similarities between these studies like levels of education, the 
number of employees, gender of the Household's Head, agricultural land area, participation in social organizations of household members, the ability to access credit.

The mobilization of resources for urban development, industrialization, and modernization has been studied in different directions according to Morrison and Schwarts (1992), when examining factors affecting the decision to select investment location of the investor, with four groups of aspects analyzed in the study: human resources, technological resources, investment in the environment, and market development with 28 evaluation criteria to determine the attributes of the cluster. In the cost approach, the main factors influencing the investor's decision on investment position are identified, including transportation costs, labor costs, proximity to supporting industrial facilities, and advantages in logistics and marketing. Research by Porter (2011), on competitive advantage, investment location, industry complexes/career, and corporate strategy suggested a dynamic approach to motivations investment decisions, highlighting the role of industrial complexes/career in the competitive strategy of enterprises, at the same time, analyzing the role of investment locations in the process of forming enterprises' competitive advantage. While, research by Blomstrom and Kokko (1998), Blomström and Sjöholm (1998, 1999), Melnyk et al. (2014), Popescu (2008) provided policy suggestions to step up the attraction of foreign direct investment in industrial parks in particular as well as in that country in general. The research methods applied in the study is a descriptive statistical method with data collected by questionnaires with enterprises operating in national industrial parks such as Kolin- Ovcary, Nosovice, Mosh Joseph. Through the data collected, the author calculated the impact of industrial parks on the local socio-economic development - through the tax collected by the government, the number of creating new jobs. Since then, the authors gave some policy recommendations for attracting and using foreign direct investment.

The development of cities requires relatively huge resources, not only capital but also human resources and other resources. Inherited previous studies, this study is carried out to calculate the resource needs for the development of a typical city in Vietnam, especially in the context of the present integration. From there, it can be used as a base for expansion for other cities in the country. Resources play an important role in socio-economic development as well as urban areas in Vietnam in particular and general areas. To enhance the attraction of resources, promoting the positive influencing factors and limiting the negative influencing factors. Inheriting previous studies, this study is carried to study the impact of these factors on resource attraction for urban development in Vietnam.

\section{Research methodology}

\subsection{Data collection methods}

Data for the research were collected from two sources:

First of all, the secondary data collected from the annual summary report of Phuc Yen City are related to urban development rate, economic growth rate, and investment of Phuc Yen City for industries, etc. Secondly, the primary data are collected from the survey of employers in Phuc Yen City, Vinh Phuc province since they are the significant contributors to the development of cities. The results of the enterprise survey help the author have a more objective and multidimensional perspective on the desire of the enterprises to one of the two main resources that are human resources when doing business and production activities. The research surveyed 116 enterprises in different fields in Vinh Yen city, Vinh Phuc province. This data was used to calculate the adaptive capacity of workers in the current urban integration and development context as assessed by enterprises. At the same time, enterprise survey data were also used by the authors to analyze the enterprises' assessment and factors affecting the ability to mobilize resources for urban development stand from the perspective of the investors themselve. Survey methods, conducted a direct survey according to convenient sampling method and there were also limitations with the convenient sampling, and this is also a limitation of the study to be able to continue to perform for the following future research.

\subsection{Analytical methods}

With the secondary data collected, the author performed an analysis of the status of local resources being used for urban development. At the same time, the Arima model has been selected to forecast the demand for investment capital for urban development over the period 2021-2030 in Vinh Yen city of Vinh Phuc province by economic sectors. With the primary data collected, the authors performed the calculation of the adaptive capacity of labor when the context changed, namely the current international economic integration and urban development. The indicators selected for the analysis of the adaptive capacity of employees were inherited from research by UNDP (2019), Quan Minh Nhut, Tran Thi Bach Yen, Pham Le Dong Hau (2012). To calculate the adaptability of workers, the author's calculation method is as follows: Because these indicators are evaluated and measured on different scales, before calculating the adaptive capacity index (ACI), the criteria will be standardized and then calculated according to the average principle according to the human development index (HDI) formula of Anand and Sen (1994), specifically the formula described as follows: 


$$
\mathrm{SI}_{\mathrm{i}}=\left(\operatorname{In}_{\mathrm{i}}-\operatorname{In}_{\min }\right) /\left(\operatorname{In}_{\max }-\operatorname{In}_{\min }\right)
$$

where:

$\mathrm{SI}_{\mathrm{i}}$ : is the normalized indicators according to criterion $i$

$\mathrm{In}_{\mathrm{i}}$ : is the average index of criterion $i$

$\operatorname{In}_{\max }$ and $\operatorname{In}_{\min }$ : are the largest and smallest indexes of criterion $i$

Once each criterion was normalized, all criteria were averaged to form the total criteria for the adaptability of labor. The formula for calculating the indicators of resources is as follows:

$$
\mathrm{IC}_{\mathrm{j}}=\sum_{1}^{\mathrm{i}} \mathrm{SI}_{\mathrm{i}} / \mathrm{i}
$$

where:

$\mathrm{IC}_{\mathrm{j}}$ : is the index of adaptive capacity

$\mathrm{SI}_{i}$ : is the normalized value of each criterion

$i$ : is the total criteria are calculated

Also, multivariate regression was carried out by the research team to analyze the factors affecting the attraction of resources for urban development. Specifically, the variables used in the study include:

Dependent variable (Y): Result of resource attraction in Phuc Yen city, Vietnam

Independent variables:

+ Human resources $(\mathrm{X} 1)$ :

+ Local policy (X2)

+ Infrastructure system (X3)

+ Local advantages (X4)

Additionally, studies have also shown that, in addition to the factors mentioned above, there are also factors affecting the attraction of resources for urban development such as local economic integration (X5), science and technology (science and technology), business development orientation (X6) and other factors belonging to the business (X7; X8). However, in this study, the authors only focus on analyzing four groups of local factors are human resources, local policies, infrastructure, and urban advantages. The study will calculate the influence of these factors on the results of resource attraction in the typical case of Phuc Yen city in Vietnam.

\subsection{Research scope}

This study focuses on forecasting the need to mobilize resources for two groups, namely the human resource group and the financial resource group. The group of human resources aiming to calculate the adaptability of labor to changing contexts is the urban development process. The research financial resources towards calculating capital needs for sectors of Phuc Yen city for urban development was dor the period 2021-2030. This is also a limitation of the research when focusing only on case studies for a typical urban form in Vietnam. In the future, the team will expand the spatial scope to overcome the limitations of their research.

\section{Research findings}

\subsection{Analysis of factors affecting resource mobilization for urban development in Phuc Yen City, Vietnam}

With the collected data, research was carried on multivariate regression to analyze the impact of these factors on the capacity to attract resources for urban development. The specific results are as follows: 
Table 2

Testing the explanation level of the model

\begin{tabular}{|c|c|c|c|c|c|c|c|c|c|}
\hline \multirow{2}{*}{ Model } & \multirow[b]{2}{*}{$\mathrm{R}$} & \multirow[b]{2}{*}{$\begin{array}{c}\mathrm{R} \\
\text { Square }\end{array}$} & \multirow[b]{2}{*}{$\begin{array}{c}\text { Adjusted R } \\
\text { Square }\end{array}$} & \multirow[b]{2}{*}{$\begin{array}{l}\text { Std. Error of the } \\
\text { Estimate }\end{array}$} & \multicolumn{4}{|c|}{ Change Statistics } & \multirow[b]{2}{*}{$\begin{array}{l}\text { Durbin- } \\
\text { Watson }\end{array}$} \\
\hline & & & & & $\begin{array}{l}\text { R Square } \\
\text { Change }\end{array}$ & $\begin{array}{c}\mathrm{F} \\
\text { Change }\end{array}$ & df1 df2 & $\begin{array}{l}\text { Sig. F } \\
\text { Change }\end{array}$ & \\
\hline 1 & $.877^{\mathrm{a}}$ & .770 & .752 & .452016626694024 & .770 & 44.669 & $8 \quad 107$ & .000 & 2.426 \\
\hline
\end{tabular}

Source: Analysis results from the author's research data

Durbin- Watson $=2.426$ coefficient $=2.426$, the research model has no autocorrelation. Explanation level of the model with adjusted $\mathrm{R}^{2}$ coefficient $=0.752$, which indicates that about $75.2 \%$ of the variation in the dependent variable is explained by the independent variables in the model. The testing results show a model that the author chooses is a relatively good choice when there are no self-correlation defects in the model and independent variables which explain more than $90 \%$ of dependent variables (The result meets requirements when $\mathrm{R}$ Square $>=0.7$ ).

Table 3

Testing the suitability of the model based on ANOVA method

\begin{tabular}{lllllll}
\hline Model & & Sum of Squares & Df & Mean Square & F & Sig. \\
\hline \multirow{2}{*}{1} & Regression & 73.014 & 8 & 9.127 & 44.669 & $.000^{\mathrm{b}}$ \\
\cline { 2 - 7 } & Residual & 21.862 & 107 & .204 & & \\
\hline
\end{tabular}

a. Dependent Variable: Y

b. Predictors: (Constant), X1, X2, X3, X4, X5, X6, X7, X8

Source: Analysis results from the author's research data

Table 4

Results of regression model

\begin{tabular}{|c|c|c|c|c|c|c|c|c|}
\hline \multirow[b]{2}{*}{ Model } & & \multicolumn{2}{|c|}{ Unstandardized Coefficients } & \multirow{2}{*}{$\begin{array}{l}\text { Standardized } \\
\text { Coefficients } \\
\text { Beta }\end{array}$} & \multirow[b]{2}{*}{$\mathrm{T}$} & \multirow[b]{2}{*}{ Sig. } & \multicolumn{2}{|c|}{ Collinearity Statistics } \\
\hline & & $\mathrm{B}$ & Std. Error & & & & Tolerance & VIF \\
\hline$\overline{1}$ & (Constant) & -2.641 & .375 & & -7.037 & .000 & & \\
\hline & $\mathrm{X} 1$ & 231 & .075 & 174 & 3.075 & .003 & .676 & 1.480 \\
\hline & $\mathrm{X} 2$ & .217 & .047 & .247 & 4.574 & .000 & .737 & 1.356 \\
\hline & $\mathrm{X} 3$ & .239 & .051 & .222 & 4.724 & .000 & .974 & 1.027 \\
\hline & X4 & .211 & .050 & .246 & 4.176 & .000 & .620 & 1.613 \\
\hline & $\mathrm{X} 5$ & .285 & .056 & .305 & 5.088 & .000 & .599 & 1.671 \\
\hline & X6 & .186 & .066 & .155 & 2.817 & .006 & .714 & 1.401 \\
\hline & $\mathrm{X} 7$ & .185 & .067 & .183 & 2.768 & .007 & .492 & 2.031 \\
\hline & $\mathrm{X} 8$ & .163 & .068 & .142 & 2.419 & .017 & .629 & 1.589 \\
\hline
\end{tabular}

a. Dependent Variable: Y

Source: Analytical results from research data of author

The factors are statistically significant, and the level affecting the ability to mobilize resources is different. The relationship between elements is in the same direction as the dependent variable, as follows:

Human Resources (X1): influence of human resources on resource mobilization with Standardized Coefficients coefficient of 0.174 , if the quality and quantity of resources meet the requirements of the units that are allowed to mobilize investment resources, the results of resource attraction will be positive.

Local policy (X2), the Standardized Coefficients coefficient of 0.247 indicates the significance and importance of this variable for resource mobilization. The good preferential policies have comparative advantages with other localities; moreover, Local government supports investors, the result of resource attraction will be better. 
+ The infrastructure system (X3) has a coefficient of 0.222 and shows the factor's position with mobilizing resources for urban development. Modern infrastructure systems will contribute to connecting and helping investors feel secure in their activities, from where the ability to mobilize resources and attract resources for urban development from investors will also be better.

+ Local advantages (X4): This is a factor showing the comparative advantage of cities in the same area. This advantage will bring positive results for resource attraction to serve the urban development goals of the locality.

One of the factors that have a great influence on the results of attracting investment resources is international economic integration (X5). Reality shows that the mobilization of urban development resources is to mobilize socialized resources, particularly from enterprises, from the population, and the most capital part of these resources is from the business. Businesses or investors from sources: At home and abroad (international), if international integration is good, there will be opportunities to approach investors. From yonder, the results of attracting resources will be greater. This is consistent with the firm's practices and prices when the Standardized Coefficients of this variable is 0.305 .

\subsection{Forecasting the need of some resources for the development of Phuc Yen city, Vietnam}

\subsubsection{Human resource demand for urban development}

Survey results for enterprises on human resource needs show that the adaptive capacity of labor in the context of integration is able to meet the needs of enterprise development and the promotion of urban development, shown as follows:

\section{Table 5}

Adaptive capacity of human resources

\begin{tabular}{|c|c|c|c|c|c|c|c|c|c|}
\hline Criteria & 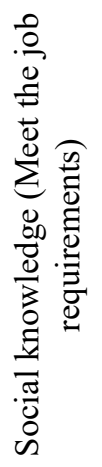 & 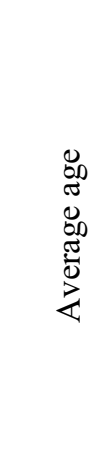 & 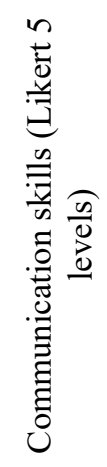 & 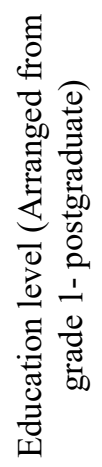 & 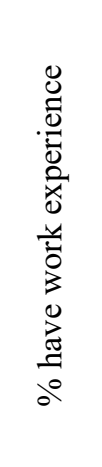 & 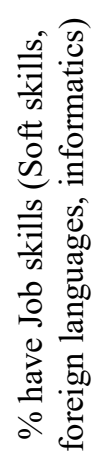 & 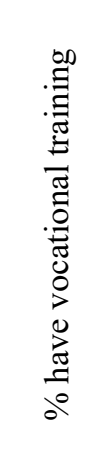 & 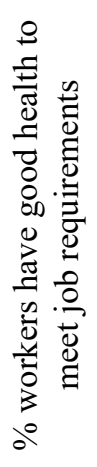 & 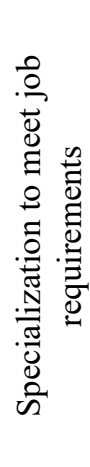 \\
\hline Real value & 2.16 & 31.54 & 3.16 & 12.08 & 62.18 & 52.16 & 52.8 & 92.3 & 72.08 \\
\hline Minimum value & 1 & 16 & 1 & 0 & 0 & 0 & 0 & 0 & 0 \\
\hline Maximum value & 3 & 48 & 5 & 15 & 100 & 100 & 100 & 100 & 100 \\
\hline Adaptive index is normalized & 0.58 & 0.49 & 0.54 & 0.81 & 0.62 & 0.52 & 0.53 & 0.92 & 0.72 \\
\hline Adaptive capacity index & & & & & & & & & \\
\hline
\end{tabular}

The calculation results show that the adaptive capacity of Vietnamese workers is relatively good at about 0.64 . This result is calculated based on the following specific criteria:

Firstly, about social knowledge (to meet the requirements of the job), in the current integration conditions, meeting job requirements to be able to compete with not only domestic workers but also international workers, adapting and creating a competitive advantage is an advantage for Vietnamese workers. According to the three ratings that are responsive, nonresponsive, and normal, the average score from the survey subjects is 2.16 points.

Secondly, the criteria for communication ability: This criterion is assessed at an average of about 3.16 points / 5 points, and the communication level depends on the qualities of each worker, but also requires training. The supplementary training process is the practice in the working process will help employees communicate better because communication directly affects the success of the job.

Thirdly, work experience, with $62.18 \%$ of the surveyed enterprises saying that the recruited workers have had work experience, however, when changing the working environment, they will have to adapt to a new environment, a new job. Having experience 
working in jobs close to new positions will contribute to supporting employees. At the same time, employers also tend to give preference to experienced workers. The workers have no experience causing difficulties for the operation of the enterprises, thereby affecting the development of urban.

Fourthly, Job Skills: These are skills that play a significant role and are always interested in the context of the industrial revolution 4.0 as well as in the present international integration context, such as soft skills, information technology skills, and foreign languages. The lack of these skills is a disadvantage for workers who want to get access to jobs with foreign elements. In the present context, these requirements are relatively usual and necessary. However, a large proportion of Vietnamese workers do not fully meet these soft skills, including high-quality labor. These common intangibles have created barriers to integration and access to work in the context of internationalization for Vietnamese workers. The research findings show that only $52.16 \%$ of workers meet these conditions at present. Enterprises required workers need to have the skills for the work because it directly affects the business results of the enterprises whereby affecting the socio-economic development of the city.

Fifthly, on expertise and health of workers: These are relatively highly appreciated factors, and the reality shows that the Vietnamese employees are qualified, professional, persistent, and very hard-working, with good health for the working process. These factors create plus points for Vietnamese workers in the current context of integration and competition in the labor market.

\subsubsection{Capital needs for urban development}

Based on data on capital sources for urban development in the previous period, the Arima model has been selected to forecast the capital needs for urban development of Phuc Yen city from 2021-2030. Forecast results by the sectors, specific results are as follows:

First, the results of forecast performance for capital needs for the industry

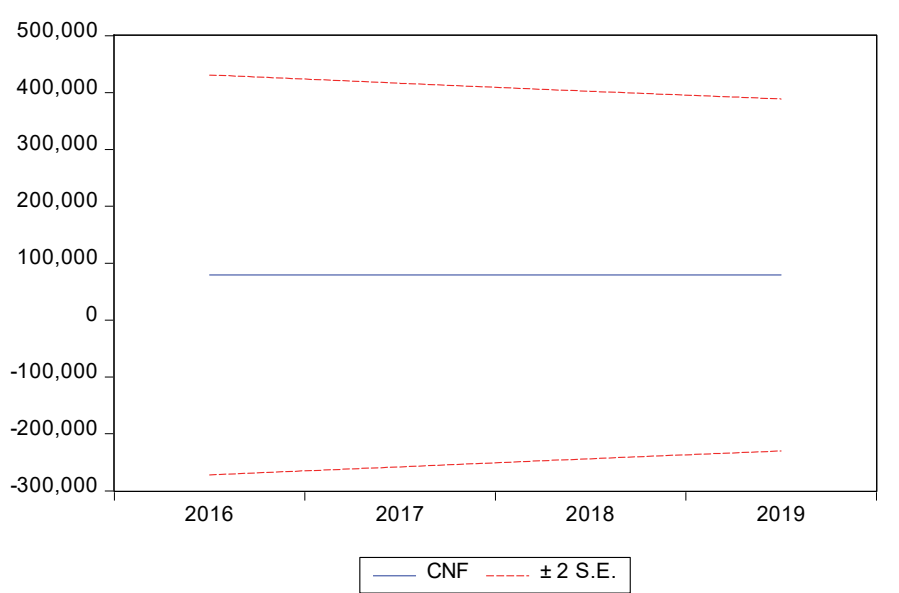

\begin{tabular}{|ll|}
\hline Forecast: CNF \\
Actual: CN \\
Forecast sample: 20162019 \\
Included observations: 4 & \\
Root Mean Squared Error & 8106.791 \\
Mean Absolute Error & 7307.976 \\
Mean Abs. Percent Error & 8.312768 \\
Theil Inequality Coefficient & 0.048963 \\
$\quad$ Bias Proportion & 0.812636 \\
$\quad$ Variance Proportion & 0.180983 \\
$\quad$ Covariance Proportion & 0.006381 \\
Theil U2 Coefficient & 1.582278 \\
Symmetric MAPE & 8.748038 \\
\hline
\end{tabular}

Source: Analysis results from the author's research data

Fig. 1. Testing the suitability of the model

Table 6

The results of forecast performance for capital needs for the industry (Unit: Billion VND)

\begin{tabular}{ccccc}
\hline Year & CN & CN_ARIMA & Year & 2020 \\
\hline 2011 & 65532.3 & 65532.3 & 2021 & 78199.092 \\
2012 & 62582.2 & 62582.2 & 2022 & 78209.1415 \\
2013 & 74023.3 & 74023.3 & 2023 & 78218.689 \\
2014 & 76550 & 76550 & 2024 & 78227.762 \\
2015 & 81206.5 & 81206.5 & 2025 & 78236.382 \\
2016 & 83100 & 83100 & 2026 & 78244.573 \\
2017 & 84525 & 84525 & 2027 & 78252.356 \\
2018 & 92220 & 92220 & 2028 & 78259.7523 \\
2019 & 85768.2 & 85768.2 & 2029 & 78266.7794 \\
& & & 2030 & 78273.4564 \\
\hline
\end{tabular}


The unit of calculation of the capital need is billion VND, according to the calculation results, forecasts about the investment capital needs for urban development in Phuc Yen city in 2021 is 78209.14 billion VND for industry, this figure increases to about 78279.8 billion by 2030 .

Second, forecast performance results for the capital needs of the agricultural sector

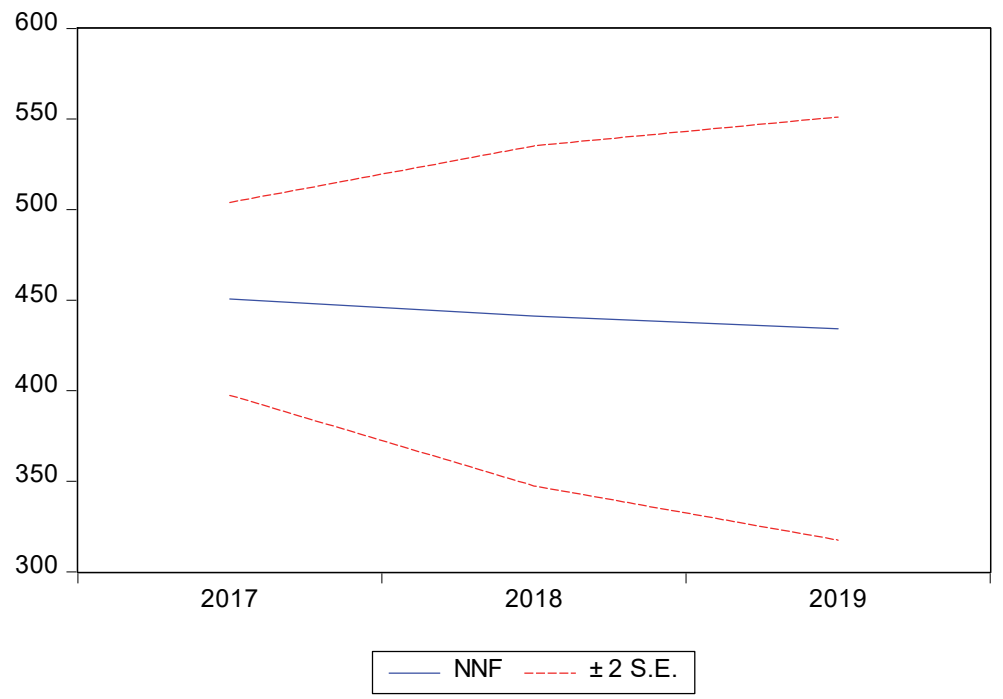

\begin{tabular}{|c|c|}
\hline \multicolumn{2}{|l|}{ Forecast: NNF } \\
\hline \multicolumn{2}{|l|}{ Actual: NN } \\
\hline \multicolumn{2}{|l|}{ Forecast sample: 20172019} \\
\hline \multicolumn{2}{|l|}{ Included observations: 3} \\
\hline Root Mean Squared Error & 45.68704 \\
\hline Mean Absolute Error & 43.05259 \\
\hline Mean Abs. Percent Error & 8.801143 \\
\hline Theil Inequality Coefficient & 0.049266 \\
\hline Bias Proportion & 0.887999 \\
\hline Variance Proportion & 0.027967 \\
\hline Covariance Proportion & 0.084033 \\
\hline Theil U2 Coefficient & 1.769756 \\
\hline Symmetric MAPE & 9.253587 \\
\hline
\end{tabular}

Fig. 2. Testing the suitability of the model

Source: Analysis results from the author's research data

Table 7

The results of forecast performance for capital needs for the agricultural sector (Unit: Billion VND)

\begin{tabular}{|c|c|c|c|c|}
\hline Year & $\mathrm{NN}$ & NN ARIMA & Year & NN ARIMA \\
\hline 2011 & 358.6 & 358.6 & 2020 & 432.9198 \\
\hline 2012 & 376.3 & 376.3 & 2021 & 427.80131 \\
\hline 2013 & 391.6 & 391.6 & 2022 & 423.90660 \\
\hline 2014 & 397 & 397 & 2023 & 420.94310 \\
\hline 2015 & 414.9 & 414.9 & 2024 & 418.68816 \\
\hline 2016 & 443.4 & 443.4 & 2025 & 416.97237 \\
\hline 2017 & 478.1 & 478.1 & 2026 & 415.66681 \\
\hline 2018 & 505.1 & 505.1 & 2027 & 414.67341 \\
\hline \multirow[t]{3}{*}{2019} & 472 & 472 & 2028 & 413.91752 \\
\hline & & & 2029 & 413.342373 \\
\hline & & & 2030 & 412.90473 \\
\hline
\end{tabular}

Source: Author's calculations

The unit of calculation of the capital need is billion VND according to the calculation results, it forecasted that in 2021, the demand for investment capital for urban development in Phuc Yen city would be about 427.80 billion VND for the agricultural sector, this number increases to about 412.9 billion VND in 2030. The fact that the contribution of the agricultural sector in the economic structure of localities is not great, especially in urban areas. Capital needs for this sector are also relatively low-lying. Third, the results of the implementation of the forecast for the capital needs of the service sector
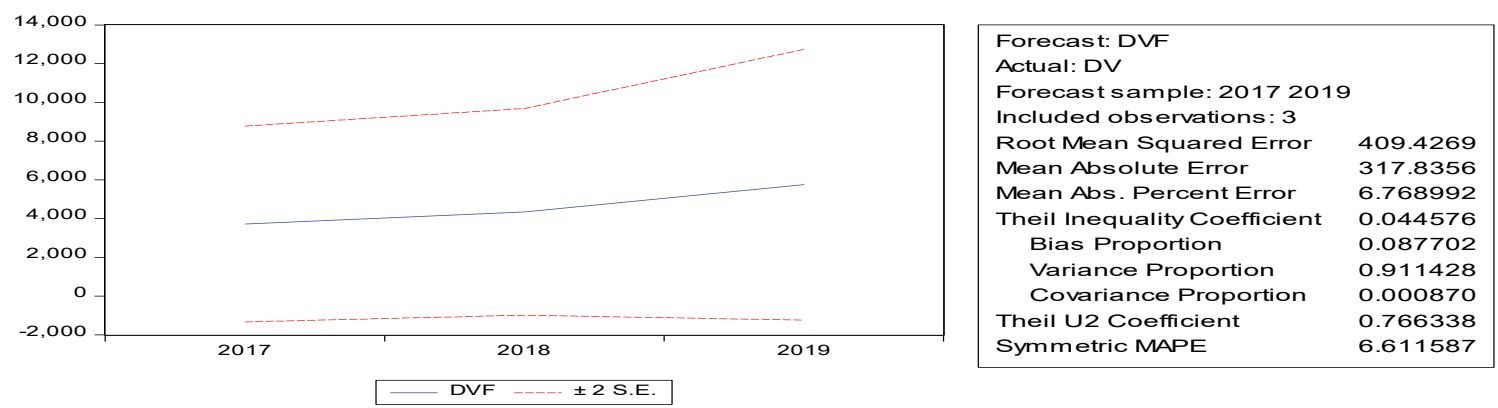

Fig. 3. Testing the suitability of the model

Source: Analysis results from the author's research data 
Table 8

The results of forecast performance for capital needs for the service sector (Unit: Billion VND)

\begin{tabular}{|c|c|c|c|c|}
\hline Year & DV & DV_ARIMA & Year & DV_ARIMA \\
\hline 2011 & 4600 & 4600 & 2020 & 6885.7957 \\
\hline 2012 & 5288.4 & 5288.4 & 2021 & 7240.2031 \\
\hline 2013 & 5980 & 5980 & 2022 & 6409.45071 \\
\hline 2014 & 7050 & 7050 & 2023 & 5089.6187 \\
\hline 2015 & 8389.5 & 8389.5 & 2024 & 4239.4981 \\
\hline 2016 & 3613.5 & 3613.5 & 2025 & 4393.8469 \\
\hline 2017 & 4015 & 4015 & 2026 & 5340.5751 \\
\hline 2018 & 4330 & 4330 & 2027 & 6345.3360 \\
\hline \multirow[t]{3}{*}{2019} & 5100 & 5100 & 2028 & 6711.3888 \\
\hline & & & 2029 & 6254.5304 \\
\hline & & & 2030 & 5375.6199 \\
\hline
\end{tabular}

The unit of calculation of the capital need is billion VND, according to the calculation results, it is forecasted that the demand for investment capital for urban development in Phuc Yen city will be about 7240.2 billion VND in 2021 for the service industry, this figure increases to about 5375.62 billion by 2030. For Phuc Yen city of Vietnam, industry, and services make up a large proportion and contribute to GDP an enormous proportion of the urban. Therefore, the resources mobilized for the development of the industry are relatively high, and so is the need for capital. Based on the results, the study proposes some solutions to enhance resource mobilization as well as promote the urban development of Phuc Yen in Vietnam.

\section{Recommendations}

It is necessary to develop supporting mechanisms and policies to attract, exploit, and maximize socialized capital to invest in large and modern projects through investment projects in the form of public-private partnerships (PPP), funds of enterprises and people. Organizing a list of urgent investment projects and a list of reciprocal land funds to encourage interested investors to implement; priority given to PPP projects with direct payback through BOT or BTO contracts. Applying 4.0 technology in the policy development process and promoting policies to enterprises and people, towards building Phuc Yen city into a Smart city, policy mechanisms implemented "Fast, compact and efficient". It is also necessary to prioritize the mobilization of investment resources for tourism and trade development in Phuc Yen city, especially Dai Lai tourist area.

Improving the quality of growth, labor productivity, investment environment, creating a competitive advantage of the city compared to other Hanoi's satellite urban areas

Completing infrastructure of urban areas of the city to be able to meet investment attraction, socio-economic development, and capital construction projects with a high concentration on vital plans of the City capital city and works allocated to complete the year's progress. Building Phuc Yen city has a competitive advantage compared to other localities in the province and other localities in the region.

Developing detailed planning and plans to mobilize resources for tourism development. Actively remove difficulties and obstacles for significant tourism and service investment projects to be implemented on schedule. Focus on developing many useful and high added value service industries. Strengthen trade promotion activities, market management, fight smuggling, trade fraud, and counterfeit goods. Utilizing science and technology applications and modern communication channels to promote Phuc Yen tourism to domestic and foreign tourists.

Developing policies to improve the investment environment, improving competitiveness, focus on attracting and developing large enterprises, reputation, capacity, and producing high-quality products, does not affect the environment; encouraging innovation technologies in production and business, meeting international integration, promoting the economic - social development of the province quickly and sustainably. Inheriting and applying modern technology in the world, combining and attracting enterprises to use modern technology in the world to enhance Phuc Yen's position in the current increasingly competitive between not only localities in the province but also with surrounding localities and regions.

Reform administrative procedures, ensure openness and convenience, overcome troubles, and reduce Recosts for investors. Apply information technology in the process of solving administrative formalities to reducing the workload for employees of the administrative units of the City. Gradually build Phuc Yen into a Smart City in activities handling office procedures. Thence, improving competitiveness for Phuc Yen city. 


\section{References}

Alam, K. F., \& Stafford, L. W. T. (1985). Tax incentives and investment policy: A survey report on the United Kingdom manufacturing industry. Managerial and Decision Economics, 6(1), 27-32.

Benayas, J. R., Martins, A., Nicolau, J. M., \& Schulz, J. J. (2007). Abandonment of agricultural land: an overview of drivers and consequences. CAB reviews: Perspectives in Agriculture, Veterinary Science, Nutrition and natural resources, 2(57), $1-14$.

Blomström, M., \& Kokko, A. (1998). Multinational corporations and spillovers. Journal of Economic Surveys, $12(3), 247-277$.

Blomström, M., \& Sjöholm, F. (1999). Technology transfer and spillovers: Does local participation with multinationals matter?. European economic review, 43(4-6), 915-923.

Bryceson. D. F. (1996). Deagrarianization and rural employment in sub-Saharan Africa: A sectoral perspective. World Development, 24(1), 97-111

Damborský, M., Wokoun, R., \& Krejčová, N. (2013). The effectiveness of industrial zones support in the Czech republic. Journal of Ekonomika a Management, 16(4), 104-117,

Dunning, J. H. (1997). Trade, location of economic Activity and the MNE: A search for Approach in the international allocation of economic activity. Edited by Bertil Ohlin Hesselborn and per Magues Wijiman, New York, Holmes and Meier Publisher.

Kotler, P., Hamlin, M. A., Haider, D. H., \& Rein, I. (2002). Marketing Asian places: Attracting investment, industry, and tourism to cities, states and nations. John Wiley \& Sons Incorporated.

Kotler, P., \& Gertner, D. (2002). Country as brand, product, and beyond: A place marketing and brand management perspective. Journal of brand management, 9(4), 249-261.

Jansen, H. G., Pender, J., Damon, A., Wielemaker, W., \& Schipper, R. (2006). Policies for sustainable development in the hillside areas of Honduras: A quantitative livelihoods approach. Agricultural economics, 34(2), 141-153.

Gilmore, A., O'Donnell, A., Carson, D., \& Cummins, D. (2003). Factors influencing foreign direct investment and international joint ventures. International Marketing Review, 20(2), 195-215.

Le Hoang Ba Huyen. (2015). factors affecting Foreign Direct Investment in Thanh Hoa province, VNU Journal of Science: Economics and Business, 31(2), 26-37.

Melnyk, L., Kubatko, O., \& Pysarenko, S. (2014). The impact of foreign direct investment on economic growth: case of post communism transition economies. Problems and perspectives in Management, 12(1), 17-24.

Morrison, C. J., \& Schwartz, A. E. (1992). State infrastructure and productive performance (No. w3981). National Bureau of Economic Research.

Popescu (2008). Eco-industrial parks - an opportunity for the developing countries to achieve sustainable development. Zagreb international review of economics and business, 11 (special issue), 21-33.

Porter, M. E. (2011). Competitive advantage of nations: creating and sustaining superior performance. simon and schuster.

Quan Minh Nhựt, Trần Thị Bạch Yến, Phạm Lê Đông Hậu (2012). The assessment of training quality of human resource in the Mekong delta of the Universities. Science Journal. 22b, 273-282. https:/sj.ctu.edu.vn/ql/docgia/tacgia-4304/baibao5756.html

Tran Quang Tuyen. (2013). Livelihood strategies for coping land loss among households in VietNam's sub-urban areas. Asian Social Science, 9(15), 33-46

Tran Quang Tuyen, Vu Van Huong. (2014). The impact of land loss on household income: The case of HaNoi's sub-urban areas, Viet Nam,

Tuyen, T. Q., \& Van Huong, V. (2014). The impact oof land loss on household income-The case of Hanoi's sub-urban areas, Vietnam. International Journal of Business and Society, 15(2), 339 - 358

UNDP (2019). Human development 2019.

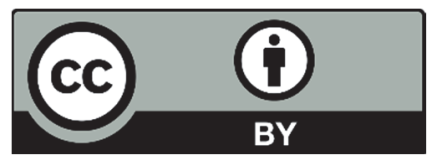

(C) 2021 by the authors; licensee Growing Science, Canada. This is an open access article distributed under the terms and conditions of the Creative Commons Attribution (CC-BY) license (http://creativecommons.org/licenses/by/4.0/). 